\title{
Sex Difference in the Association between Sleep Duration and Thyroid Disease among South Korean Adults
}

\author{
Jeong Hyun Ahn', Jin Young Nam², Soojin Park \\ ${ }^{1}$ Undergraduate Student, Department of Healthcare Management, Eulji University, Sungnam; ${ }^{2}$ Professor, Department of Healthcare Management, Eulji \\ University, Sungnam; ${ }^{3}$ Graduate Student, Department of Healthcare Management, Eulji University, Sungnam, Korea
}

Objectives: The study aimed to investigate sex differences associated with sleep duration and the prevalence of thyroid disease among South Korean adults. Methods: This cross-sectional study included 17,555 adults who participated in the Korea National Health and Nutrition Examination Survey from 2016 to 2018. Sleep duration was categorized into three groups (insufficient, $<7$ hour; normal, 7-8 hour; prolonged, $\geq 9$ hour). A chi-squared test was performed to assess baseline characteristics. Multiple logistic regression analysis was used to identify the association between general characteristic and the prevalence of thyroid disease. In subgroup analysis, multiple logistic regression analysis was performed to find the association between sleep duration and prevalence of thyroid disease by sex. Results: For men, insufficient and prolonged sleep durations were increased risk of thyroid disease compared with normal sleep duration (insufficient sleep: odds ratio, $\mathrm{OR}=1.85,95 \%$ confidence interval, $\mathrm{Cl}=1.19-2.87$; prolonged sleep: $\mathrm{OR}=1.71,95 \%$ $\mathrm{Cl}=1.02-2.87$ ). Conclusions: This study found that men with insufficient and prolonged sleep were associated with thyroid disease. Further studies are needed to identify the relationship between sleep duration, thyroid disease, and sleep quality by sex.

Key words: Sex difference, Sleep duration, Thyroid disease

\section{INTRODUCTION}

Sleep is an important component of health status. Although many people recognize that sleep is essential for life, they do not complete the required sleep duration due to social, leisure, or business-related activities [1]. If the situation persists, it can negatively affect lifestyle and mental status and can lead to the occurrence of several diseases. In particular, insufficient sleep aggravates depression, physical health, immune, cardiovascular, and metabolic syndrome [2]. It affects patients with chronic pain and physical and psychological symptoms [3]. Sleep is related to an increased risk of mortality [4] and affects metabolic syndrome by sex [5]. Increased risk of all-cause mortality such as ischemic heart disease, other heart disease, cerebrovascular accidents, cancer, suicide and homicide were associated with short and long sleep duration [4]. Concerning metabolic syndrome, men are associated with short sleep duration, and

Corresponding author: Jin Young Nam

553 Sanseongdae-ro, Sujeong-gu, Seongnam 13135, Korea

Tel: +82-31-740-7451, E-mail: jynam@eulji.ac.kr

Received: July 12, 2021 Revised: August 22, 2021 Accepted: August 25, 2021

No potential conflict of interest relevant to this article was reported. women are affected by long sleep duration [5]. Therefore, it is essential to sleep properly to maintain adequate sleep duration and prevent diseases.

There are many thyroid diseases such as autoimmune disease and Graves' disease, which cause hyperthyroidism and Hashimoto's thyroiditis, which results in hypothyroidism [6]. Based on the reference range of serum thyroid stimulating hormone (TSH) (0.62-6.68 mIU/L), the prevalence of subclinical hypothyroidism and subclinical hyperthyroidism was $0.73 \%$ ( $0.40 \%$ men, $1.10 \%$ women) and $3.10 \%$ (2.26\% men, $4.04 \%$ women), respectively, in Korea, from 2013-2015 [7]. Previous studies have investigated the association between sleep and thyroid diseases [8]. Sleep can affect hormone secretion, thyroid dysfunction, subclinical hyperthyroidism, and subclinical hypothyroidism [8]. Insufficient sleep indicated a significantly increased risk of subclinical hyperthyroidism not hypothyroidism; however, prolonged sleep were elevated risk of subclinical hyperthyroidism and hypothyroidism [8]. A previous study indicated an

How to cite this article:

Ahn JH, Nam JY, Park S. Sex difference in the association between sleep duration and thyroid disease among South Korean adults. J Health Info Stat 2021;46(3):337-343. Doi: https://doi.org/10.21032/ jhis.2021.46.3.337

(c) It is identical to the Creative Commons Attribution Non-Commercial License (https://creativecommons.org/licenses/by-nc/4.0) which permit sunrestricted non-commercial use, distribution and reproduction in any medium, provided the original work is properly cited.

(C) 2021 Journal of Health Informatics and Statistics 
increase in serum concentrations of fT3 and fT4 among individuals with sleep restriction compared to normal sleepers [9]. Furthermore, acute partial sleep deprivation has been shown to be influenced by endocrine homeostasis, health, and wellbeing status [9].

Although numerous studies have shown the associations between sleep duration and thyroid hormones, little is known about whether sleep durations were associated with thyroid disease. Further, few studies have investigated the association between sleep duration and the prevalence of thyroid disease according to sex. Thus, our study examined sleep duration and thyroid disease according to sex among South Korean adults, using data from the Korea National Health and Nutrition Examination Survey (KNHANES) from 2016 to 2018.

\section{METHODS}

\section{Study population and database information}

The KNHANES is a national questionnaire designed to analyze the health and nutrition stations among Koreans and is often used as primary data. The questionnaire provides objective and standardized sources while estimating the prevalence of diseases, conditions, and risk behaviors [10]. The study data were extracted from the seventh KNHANES, conducted from 2016-2018. First, 24,269 participants were identified from the KNHANES VII-3. We excluded the data collected from participants who were $<19$ years $(n=4,880)$, cases with missing information concerning the average sleep time per day during the weekday $(\mathrm{n}=1,116)$ and weekend $(\mathrm{n}=1)$, as well as cases involving no responses concerning average sleep time per day during the weekday $(\mathrm{n}=711)$ and the weekend $(n=6)$. After excluding the data, 17,555 individuals $(7,641$ men, 9,914 women) were included in this study.

\section{Definition of thyroid disease}

Thyroid disease includes autoimmune disease, Graves' disease, Hashimoto's thyroiditis, hyperthyroidism, and hypothyroidism [6]. In this study, participants were classified as having thyroid diseases and not having thyroid disease. Thyroid disease was defined as participants who responded "yes" to the following questions from the KNHANES: 1) Have you been diagnosed with thyroid disease by a physician? 2) Are you currently suffering from thyroid disease? Following these questions, individuals were defined as having thyroid disease diagnosed by a physician and currently suffering from thyroid disease. Participants without thyroid disease were defined as individuals who answered "no" to the above-mentioned questions.

\section{Assessment of sleep duration}

Sleep duration was assessed by the following questions: (1) On the weekday, what time did you go to sleep and wake up? (2) On the weekend, what time did you go to sleep and wake up? Using these questions, we calculated the average sleep duration on weekdays and weekends. We classified individuals into three groups according to previous research [11]: insufficient sleepers ( $<7$ hour/day), normal sleepers (7-8 hour/day), and prolonged sleepers ( $\geq 9$ hour/day).

\section{Covariates}

The following covariates were obtained using a standardized questionnaire in the KNHANES: sex, age, household income, education, marital status, current smoking, high-risk alcohol consumption, body mass index, working hours, physical activity, and year. The participants were stratified by age into five groups: 19-29 years, 30-39 years, 40-49 years, $50-59$ years, and $\geq 60$ years of age. The participants were stratified by household income into four categories: low, low-moderate, moderate-high, high. The individuals were divided by education into four groups: elementary school, middle school, high school, and college and above. Current smoking was defined as participants who smoked $>100$ cigarettes in their lifetime and current smokers [12]. High-risk alcohol consumption was defined as the consumption of more than 14 drinks per week for men and 10 drinks per week for women [11]. Body mass index (BMI) was stratified into three groups: underweight $\left(\mathrm{BMI}<18.5 \mathrm{~kg} / \mathrm{m}^{2}\right)$, normal $\left(18.5 \mathrm{~kg} / \mathrm{m}^{2} \leq \mathrm{BMI}<25 \mathrm{~kg} / \mathrm{m}^{2}\right)$, and obese $\left(\mathrm{BMI} \geq 25 \mathrm{~kg} / \mathrm{m}^{2}\right)[13]$. Working hours per week were classified into five groups: not working, $<20$, 20-39, 40-59, and $\geq 60$ [14]. Physical activity was defined as moderate-intensity physical activity for more than 150 minutes per week, high level of physical activity for more than 75 minutes, or a mix of moderate-and high-intensity physical activity [15].

\section{Statistical analysis}

We assessed the association between sleep duration and the prevalence of thyroid disease according to sex. A chi-squared test was performed to assess baseline characteristics. Multiple logistic regression analyses were performed to calculate odds ratio (OR) and 95\% confidence interval (CI) for general characteristic and thyroid disease. Sleep duration and thyroid 
Table 1. General characteristics of study population in the Korea National Health and Nutrition Examination Surveys 2016-2018

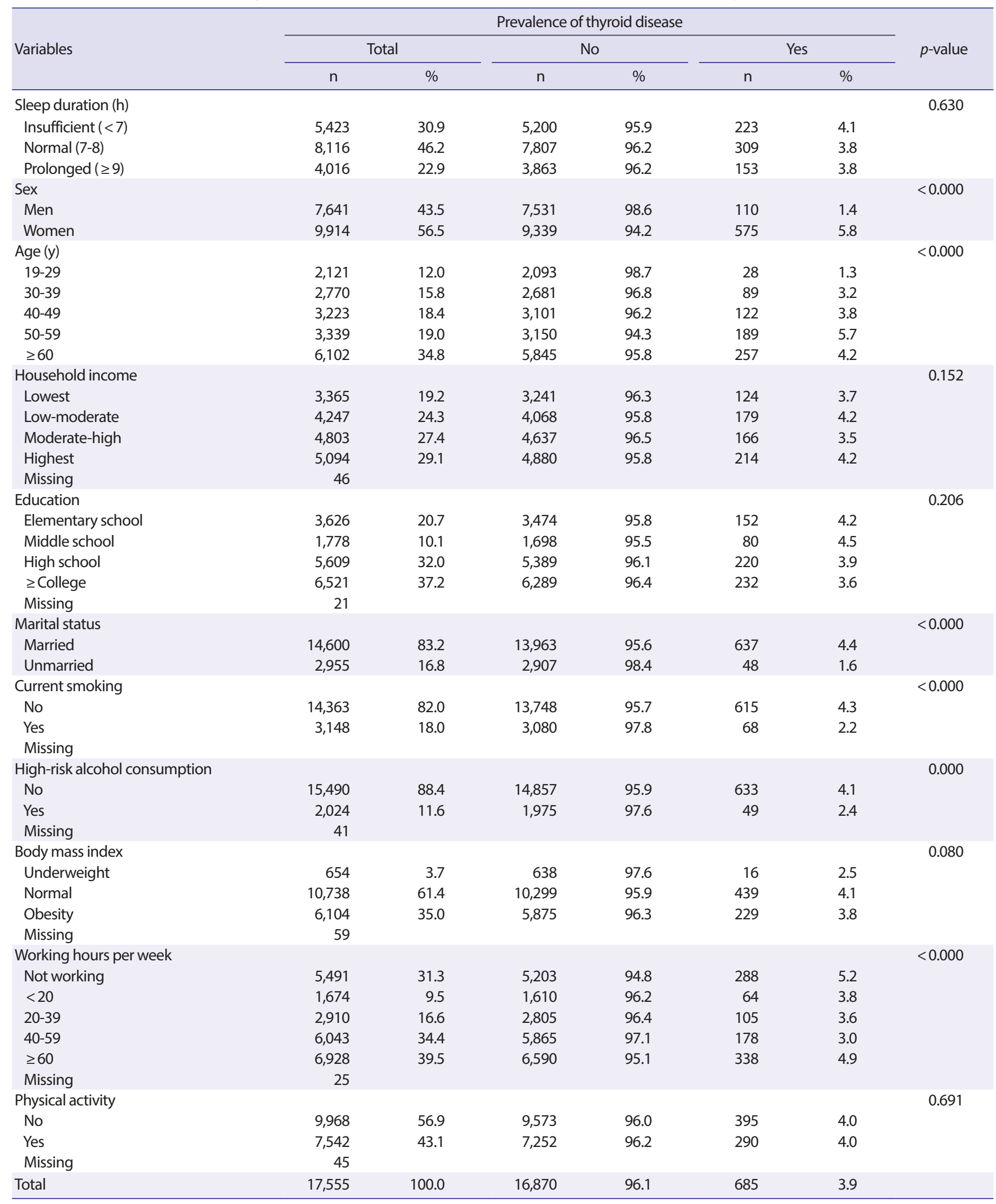


Table 2. The association between general characteristic and prevalence of thyroid disease among Korean adults in the Korean National Health and Nutrition Examination Surveys 2016-2018

\begin{tabular}{|c|c|c|c|c|}
\hline \multirow{2}{*}{ Variables } & \multicolumn{4}{|c|}{ Prevalence of thyroid disease } \\
\hline & OR & \multicolumn{2}{|c|}{$95 \% \mathrm{Cl}$} & $p$-value \\
\hline \multicolumn{5}{|l|}{ Sleep duration (h) } \\
\hline Insufficient $(<7)$ & 1.00 & 0.84 & 1.20 & 0.804 \\
\hline Normal (7-8) & \multicolumn{4}{|c|}{ Reference } \\
\hline Prolonged ( $\geq 9)$ & 1.05 & 0.86 & 1.29 & 0.605 \\
\hline \multicolumn{5}{|l|}{ Sex } \\
\hline Men & \multicolumn{4}{|c|}{ Reference } \\
\hline Women & 4.52 & 3.56 & 5.73 & $<0.000$ \\
\hline \multicolumn{5}{|l|}{ Age (y) } \\
\hline $19-29$ & \multicolumn{4}{|c|}{ Reference } \\
\hline $30-39$ & 2.08 & 1.24 & 3.49 & 0.339 \\
\hline $40-49$ & 2.43 & 1.44 & 4.11 & 0.585 \\
\hline $50-59$ & 3.88 & 2.29 & 6.58 & $<0.000$ \\
\hline$\geq 60$ & 3.30 & 1.91 & 5.70 & 0.001 \\
\hline \multicolumn{5}{|l|}{ Household income } \\
\hline Lowest & \multicolumn{4}{|c|}{ Reference } \\
\hline Low-moderate & 1.21 & 0.94 & 1.55 & 0.221 \\
\hline Moderate-high & 1.02 & 0.78 & 1.33 & 0.245 \\
\hline Highest & 1.23 & 0.94 & 1.61 & 0.153 \\
\hline \multicolumn{5}{|l|}{ Education } \\
\hline Elementary school & \multicolumn{4}{|c|}{ Reference } \\
\hline Middle school & 1.24 & 0.92 & 1.65 & 0.820 \\
\hline High school & 1.40 & 1.07 & 1.82 & 0.153 \\
\hline$\geq$ College & 1.47 & 1.10 & 1.97 & 0.062 \\
\hline \multicolumn{5}{|l|}{ Marital status } \\
\hline Married & 1.19 & 0.80 & 1.77 & 0.402 \\
\hline Unmarried & \multicolumn{4}{|c|}{ Reference } \\
\hline \multicolumn{5}{|l|}{ Current smoking } \\
\hline No & \multicolumn{4}{|c|}{ Reference } \\
\hline Yes & 1.15 & 0.86 & 1.54 & 0.342 \\
\hline \multicolumn{5}{|c|}{ High-risk alcohol consumption } \\
\hline No & \multicolumn{4}{|c|}{ Reference } \\
\hline Yes & 1.00 & 0.73 & 1.38 & 0.986 \\
\hline \multicolumn{5}{|l|}{ Body mass index } \\
\hline Underweight & 0.64 & 0.38 & 1.07 & 0.078 \\
\hline Normal & \multicolumn{4}{|c|}{ Reference } \\
\hline Obesity & 1.02 & 0.86 & 1.21 & 0.098 \\
\hline \multicolumn{5}{|c|}{ Working hours per week } \\
\hline Not working & 1.26 & 1.02 & 1.56 & 0.334 \\
\hline$<20$ & 1.05 & 0.77 & 1.42 & 0.062 \\
\hline $20-39$ & 0.94 & 0.73 & 1.21 & 0.007 \\
\hline $40-59$ & \multicolumn{4}{|c|}{ Reference } \\
\hline$\geq 60$ & 1.19 & 0.85 & 1.66 & 0.281 \\
\hline Physical activity & & & & \\
\hline No & 0.92 & 0.78 & 1.08 & 0.281 \\
\hline Yes & & Refe & nce & \\
\hline
\end{tabular}

OR, Odds ratio; $\mathrm{Cl}$, confidence interval.

Adjusted for sex, age, household income, education, marital status, current smoking, high-risk alcohol consumption, body mass index, working hours, physical activity, and sleep duration. disease according to sex were used for multiple logistic regression analyses. Statistical significance was set at $p<0.05$. SAS 9.4 (SAS Institute Inc., Cary, NC, USA) was used for all statistical analyses.

\section{Ethical approval}

The KNHANES VII was approved by the institutional review board of the Korea Centers for Disease Control and Prevention for the 3rd year (2018-01-03-P-A).

\section{RESULTS}

The general characteristics of the study population are summarized in Table 1. The study included 7,641 men and 9,914 women. There were 685 and 16,870 patients with and without thyroid disease, respectively. The prevalence of thyroid disease was $1.4 \%$ and $5.8 \%$ in men and women, respectively. Approximately, 4.1\%, 3.8\%, and 3.8\% of the cases involving insufficient sleep, normal sleep, and prolonged sleep were associated with the prevalence of thyroid disease. Statistical significance was observed for sex, age, marital status, current smoking, and working hours among participants with thyroid disease ( $p$-value $<0.0001$, respectively).

Table 2 shows that the association between general characteristic and thyroid disease among South Korean adults. Women were statistically significant for thyroid disease $(\mathrm{OR}=4.52,95 \% \mathrm{CI}=3.56-5.73)$. However, the prevalence of thyroid disease was not associated with sleep duration.

In the subgroup analysis, We compared sex differences in the association between sleep duration and the prevalence of thyroid disease among South Korean adults (Figure 1). Among men, insufficient sleep (OR=1.85,

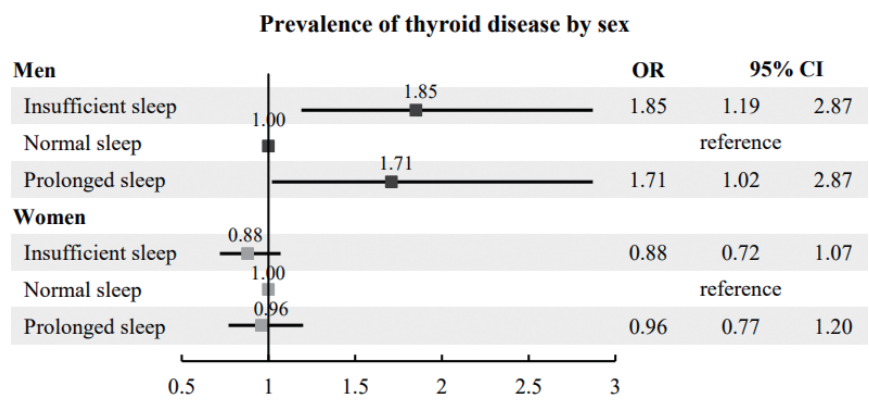

Figure 1. The sex difference in the association between sleep duration and prevalence of thyroid disease among South Korean adults. Results are demonstrated odds ratios and $95 \%$ confidence intervals. Adjusted for age, household income, education, marital status, current smoking, high-risk alcohol consumption, body mass index, working hours, physical activity, and sleep duration. 
95\% $\mathrm{CI}=1.19-2.87)$ and prolonged sleep $(\mathrm{OR}=1.71,95 \% \mathrm{CI}=1.02-2.87)$ were associated with the prevalence of thyroid disease; however, the same was not observed for women.

\section{DISCUSSION}

The results of the present study demonstrated that sleep duration was not associated with the prevalence of thyroid disease. However, we found that there was a sex difference between sleep duration and the prevalence of thyroid disease. In subgroup analysis, insufficient and prolonged sleep was related to the risk of thyroid disease for men. However, no statistically significant association was observed in women.

Most previous studies have confirmed the effects of sleep on various diseases and mortality, including cardiometabolic health [1], depression [16], chronic pain [3], increased risk of death [17], myriad adverse behavioral consequences [2] and metabolic syndrome [5]. Based on those studies, our study defined 7-8 hours as adequate sleep duration which was found to be preventive factor for thyroid disease. However, few studies have investigated the influence of sleep on thyroid function by sex, and there is a lack of information concerning the topic.

In previous studies, subclinical thyroid disease was associated with short and long sleep durations [8]. Based on this study, short sleep was increased in hyperthyroidism; however, the same was not observed in hypothyroidism. Further, short sleep was associated with a high probability of TSH suppression. Long sleep duration was associated with increased TSH secretion and subclinical hypothyroidism. In addition, both short sleep and long sleep are increased in hyperthyroidism [8].

Although there are few studies detailing sleep duration and thyroid disease, several studies have shown that changes in serum concentrations of thyroid stimulating hormone (TSH), free triiodothyronine (fT3), and free thyroxine (fT4) were controlled by circadian rhythm and partial sleep and they impacted secretory activity and thyroid function [9,18-20]. Several studies have evaluated the influence of sleep on TSH, fT3, and fT4, which are affected by thyroid and other diseases [9]. In previous studies, women were higher $24 \mathrm{~h}$-fT4 concentrations than men. In both men and women, partial sleep loss was related to a decline in free T4 and TSH; however, the results indicated that women had a statistically significant association [20]. Ferdinand [19] showed that elderly men had lower average nocturnal TSH levels compared to young individuals. In these sleep loss studies, sleep restriction for two consecutive nights among young men influenced the thyrotrophic axis [9]. Serum concentrations of fT3 and fT4 were increased, and serum TSH levels were slightly elevated in the evening hours [9]. Additionally, studies of thyrotropin secretion profiles demonstrated that TSH concentrations were slightly higher in men than in women at night [18].

According to our results, sleep duration was not associated with the prevalence of thyroid disease compared to a previous study [8]. A previous study explained that sleep duration exerted an influence on subclinical hyperthyroidism and subclinical hypothyroidism with thyroid hormone [8]. Further, our study indicated a statistical significance for men, when the correlation between insufficient sleep and prevalence of thyroid disease was analyzed by sex. Our study data from KNHANES 2016-2018 were not investigated for serum concentrations of TSH, fT3, and fT4. We could not confirm the mechanism underlying the association between sleep duration and the prevalence of thyroid disease. Therefore, our study is based on several previous studies. Thus, more studies are required to examine the influence of sleep duration on thyroid disease by sex, sleep quality, large population, and nationally representative data.

This study had several strengths. First, this study used a nationally representative sample with a large population compared to previous studies. To our knowledge, this is the first study detailing sex difference between sleep duration and the prevalence of thyroid disease. Second, various covariables were used in our studies and defined as thyroid disease with physician diagnosis and current prevalence to ensure precise measurement. Third, we investigated the wakeup time and bedtime on weekdays and weekends, respectively, using KNHANES questionnaires. Using these individuals' sleep time, we calculated the average sleep duration on weekdays and weekends.

However, there are some limitations to our study. First, sleep quality was not analyzed in the present study. The sleep quality and sleep duration affected thyroid disease [21-24], so it should be included in future studies. Second, there was no information about TSH, fT4, and fT3 in the KNHANES from 2016 to 2018. Therefore, thyroid hormones could not be measured. However, we could provide exact measurements as we used the KNHANES questionnaires for information concerning physician diagnosis and the prevalence of thyroid disease. Third, hyperthyroidism, hypothyroidism, thyroid positive nodules and Hashimoto thyroiditis were included thyroid disease in KNHANES. This study was not investigated in detail, such as the relationship between hyperthyroidism and sleep duration. 


\section{CONCLUSIONS}

In conclusion, sex differences showed a relationship between sleep duration and thyroid disease. We propose to add thyroid hormones in general health examination blood tests and include thyroid cancer in the national cancer examination for examination once every two years for men and women. Additional studies are needed to confirm the association of sleep duration and thyroid disease with sleep quality according to sex and analyses with other interesting variables.

\section{REFERENCES}

1. St-Onge MP, Grandner MA, Brown D, Conroy MB, Jean-Louis G, Coonset $\mathrm{M}$, et al. Sleep duration and quality: impact on lifestyle behaviors and cardiometabolic health: a scientific statement from the American Heart Association. Circulation 2016;134(18):e367-e386. DOI: 10. 1161/CIR.0000000000000444

2. Czeisler CA. Impact of sleepiness and sleep deficiency on public healthutility of biomarkers. J Clin Sleep Med 2011;7(5 Suppl):S6-S8. DOI: 10.5664/JCSM.1340

3. Keilani M, Crevenna R, Dorner TE. Sleep quality in subjects suffering from chronic pain. Wien Klin Wochenschr 2018;130(1-2):31-36. DOI: 10.1007/s00508-017-1256-1

4. Kripke DF, Garfinkel L, Wingard DL, Klauber MR, Marleret MR. Mortality associated with sleep duration and insomnia. Arch Gen Psychiatry 2002;59(2):131-136. DOI: 10.1001/archpsyc.59.2.131

5. Kim CE, Shin S, Lee HW, Lim J, Lee JK, Shin A, et al. Association between sleep duration and metabolic syndrome: a cross-sectional study. BMC Public Health 2018;18(1):720. DOI: 10.1186/s12889-018-5557-8

6. Merrill SJ, Mu Y. Thyroid autoimmunity as a window to autoimmunity: an explanation for sex differences in the prevalence of thyroid autoimmunity. J Theor Biol 2015;375:95-100. DOI: 10.1016/j.jtbi.2014.12.015

7. Kim WG, Kim WB, Woo G, Kim H, Cho Y, Kim TY, et al. Thyroid stimulating hormone reference range and prevalence of thyroid dysfunction in the Korean population: Korea National Health and Nutrition Examination Survey 2013 to 2015. Endocrinol Metab (Seoul) 2017; 32(1):106-114. DOI: 10.3803/EnM.2017.32.1.106

8. Kim W, Lee J, Ha J, Jo K, Lim DJ, Lee JM, et al. Association between sleep duration and subclinical thyroid dysfunction based on nationally representative data. J Clin Med 2019;8(11):2010. DOI: 10.3390/jcm-
8112010

9. Schmid SM, Hallschmid M, Jauch-Chara K, Kück MC, Lehnert H, Schultes B. Partial sleep restriction modulates secretory activity of thyrotropic axis in healthy men. J Sleep Res 2013;22(2):166-169. DOI: 10. 1111/jsr.12004

10. Kim Y. The Korea National Health and Nutrition Examination Survey (KNHANES): current status and challenges. Epidemiol Health 2014; 36:e2014002. DOI: 10.4178/epih/e2014002

11. Lee DH, Nam JY, Kwon S, Keum N, Lee JT, Shin MJ, et al. Lifestyle risk score and mortality in Korean adults: a population-based cohort study. Sci Rep 2020;10(1):10260. DOI: 10.1038/s41598-020-66742-y

12. Song JE, Kim JM, Lee MY, Jang HJ, Park KH. Effects of consumption of alcohol on intraocular pressure: Korea National Health and Nutrition Examination Survey 2010 to 2011. Nutrients 2020;12(8):2420. DOI: 10.3390/nu12082420

13. Han DH, Khang YH, Jung-Choi K, Lim S. Association between shift work and periodontal health in a representative sample of an Asian population. Scand J Work Environment \& health, 2013: p. 559-567.

14. Jeon J, Lee W, Choi WJ, Ham S, Kang SK. Association between working hours and self-rated health. Int J Environ Res Public Health 2020;17(8): 2736. DOI: 10.3390/ijerph17082736

15. Craig CL, Marshall AL, Sjöström M, Bauman AE, Booth ML, Ainsworth $\mathrm{BE}$, et al. International physical activity questionnaire: 12-country reliability and validity. Med Sci Sports Exerc 2003;35(8):1381-1395. DOI: 10.1249/01.MSS.0000078924.61453.FB

16. Yu J, Rawtaer I, Fam J, Jiang MJ, Feng L, Kua EH, et al. Sleep correlates of depression and anxiety in an elderly Asian population. Psychogeriatrics 2016;16(3):191-195. DOI: 10.1111/psyg.12138

17. Kurina LM, McClintock MK, Chen JH, Waite LJ, Thisted RA, Lauderdale DS. Sleep duration and all-cause mortality: a critical review of measurement and associations. Ann Epidemiol 2013;23(6):361-370. DOI: 10.1016/j.annepidem.2013.03.015

18. Roelfsema F, Pereira AM, Veldhuis JD, Adriaanse R, Endert E, Fliers E, et al. Thyrotropin secretion profiles are not different in men and women. J Clin Endocrinol Metab 2009;94(10):3964-3967. DOI: 10.1210/ jc.2009-1155

19. Roelfsema F, Boelen A, Kalsbeek A, Fliers E. Regulatory aspects of the human hypothalamus-pituitary-thyroid axis. Best Pract Res Clin Endocrinol Metab 2017;31(5):487-503. DOI: 10.1016/j.beem.2017.09.004 20. Kessler L, Nedeltcheva A, Imperial J, Penevet PD. Changes in serum 
TSH and free T4 during human sleep restriction. Sleep 2010;33(8): 1115-1118. DOI: 10.1093/sleep/33.8.1115

21. La J, Wang TS, Hammad AY, Burgardt L, Doffek K, Carr AA, Shaker JL, et al. Parathyroidectomy for primary hyperparathyroidism improves sleep quality: a prospective study. Surgery 2017;161(1):25-34. DOI: 10. 1016/j.surg.2016.05.047

22. He Y, Meng Z, Jia Q, Hu F, He X, Tan J, et al. Sleep quality of patients with differentiated thyroid cancer. PLoS One 2015;10(6):e0130634. DOI: 10.1371/journal.pone.0130634
23. Song L, Lei J, Jiang K, Lei Y, Tang Y, Zhu J, et al. The association between subclinical hypothyroidism and sleep quality: a population-based study. Risk Manag Healthc Policy 2019;12:369-374. DOI: 10.2147/RMHP. S234552

24. Lou X, Wang H, Tu Y, Tan W, Jiang C, Sun J, et al. Alterations of sleep quality and circadian rhythm genes expression in elderly thyroid nodule patients and risks associated with thyroid malignancy. Sci Rep 2021;

11(1):13682. DOI: 10.1038/s41598-021-93106-х

\section{국문초록}

한국성인의 수면시간과 갑상샘 질환 사이의 관계성에 대한 성별차이

안정현'·남진영'박수진 ${ }^{3}$

${ }^{1}$ 을지대학교 의료경영학과 학부생, ${ }^{2}$ 을지대학교 의료경영학과 교수, ${ }^{3}$ 을지대학교 의료경영학과 석사과정생

목적: 본 연구는 한국 성인의 수면시간과 갑상샘 유병률의 관계성에 대해 성별 차이를 파악하고자 한다.

방법: 본 단면연구는 2016년부터 2018년까지 국민건강영양조사에 참여한 성인 17,555 명이 포함되었다. 수면시간은 3 가지로 분류하였다 (불충분한 수면, 7시간 미만; 정상 수면, 7-8시간; 장시간 수면, 9시간 이상). 일반적 특성을 측정하기 위해 카이제곱 검정을 실시하였다. 일 반적 특성과 갑상샘 질환 유병률 간의 관계를 확인하기 위해 다중 로지스틱 회귀분석을 사용하였다. 하위그룹 분석에서, 다중 로지스틱 회귀분석은 성별에 따라 수면시간과 갑상샘 질환 유병률 간의 관계성을 알기 위해 시행되었다.

결과: 불충분한 수면과 장시간의 수면을 취한 남성은 정상 수면과 비교하였을 때 갑상샘 질환의 위험성이 증가하였다(불충분한 수면: $\mathrm{OR}=1.85,95 \% \mathrm{CI}=1.19-2.87$; 장시간 수면: $\mathrm{OR}=1.71,95 \% \mathrm{CI}=1.02-2.87$ ).

결론: 본 연구는 불충분하고 장시간의 수면을 취한 남성은 갑상샘 질환과 관련성이 있다. 추후 연구에서는 성별에 따른 수면시간과 갑 상샘 질환의 관계성을 수면의 질과 함께 고려할 필요가 있다.

주제어: 성별 차이, 수면시간, 갑상샘 질환 